\title{
PERANCANGAN DAN PEMBUATAN \\ RANGKAIAN PENGGERAK SPWM TIGA FASA MENGGUNAKAN MIKROKONTROLER AT89C51
}

\author{
Muhammad $^{1}$, Refdinal Nazir ${ }^{2}$ \\ Jurusan Teknik Elektro Universitas Andalas \\ e-mail: muhrahman27@gmail.com
}

\begin{abstract}
The use of grid voltage source (PLN) produces single speed value (maximum speed) of motor because grid voltage's frequency is constant $50 \mathrm{~Hz}$. Therefore, a three-phase frequency converter is used to convert dc voltage into ac voltage variable-frequency variable-voltage. The dc voltage is obtained from rectified grid ac voltage using rectifier. A three-phase variable-frequency signal generator is needed as control signal for the inverter. The use of personal computer to produce this signal is not practical and economical, while using operational amplifier as phase-shifter produces inconstant phase-shift angle at any frequency interval. In this paper, a Flash PEROM (Programmable Eraseable Read Only Memory) microcontroller AT89C51 is used to produce three-phase sinusoidal signal because the price of AT89C51 is cheaper than UV-EPROM. In addition, AT89C51 is easy to use for other application.
\end{abstract}

Keywords : AT89C51 Microcontroller, Inverter, PEROM, SPWM

\section{INTISARI}

Penggunaan sumber tegangan jala-jala PLN menghasilkan nilai kecepatan tunggal (kecepatan maksimum) motor karena besar frekuensi tegangan jala-jala PLN konstan pada nilai $50 \mathrm{~Hz}$. Karena itu inverter (frekuensi konverter) tiga-fasa digunakan untuk mengubah tegangan dc menjadi tegangan ac variabel frekuensi variabel tegangan. Tegangan dc diperoleh dari tegangan jala-jala PLN yang disearahkan menggunakan rangkaian penyearah (rectifier). Sebuah pembangkit sinyal sinusoidal tiga fasa variabel frekuensi diperlukan sebagai sinyal kontrol untuk inverter. Penggunaan komputer untuk menghasilkan sinyal tersebut tidak praktis dan ekonomis, sementara penggunaan operational amplifier sebagai penggeser fasa menghasilkan sudut pergeseran fasa yang tidak tetap di setiap rentang frekuensi. Dalam paper ini sebuah Flash PEROM (Programmable Eraseable Read Only Memory) mikrokontroller AT89C51 digunakan untuk menghasilkan sinyal sinusoidal kontrol tiga fasa variabel frekuensi karena harga AT89C51 jauh lebih murah ketimbang UV-EPROM. Selain itu AT89C51 mudah digunakan untuk aplikasi lainnya.

Kata kunci : Inverter, Mikrokontroler AT89C51, PEROM, SPWM

\section{PENDAHULUAN}

Pengaturan kecepatan putaran motor listrik ac tiga fasa sulit untuk dilakukan bila dibandingkan dengan pengaturan kecepatan motor dc. Karena pada motor ac kecepatan dipengaruhi oleh dua variabel yakni tegangan dan frekuensi jala-jala PLN, sementara pada motor dc kecepatan hanya dipengaruhi oleh tegangan input dc.

Untuk mengatur kecepatan motor ac, tegangan jala-jala PLN tidak dapat digunakan langsung sebagai suplai tegangan input motor karena frekuensi tegangan jala-jala PLN bernilai tetap 50Hz. Tegangan jala-jala PLN terlebih dahulu diubah menjadi tegangan searah menggunakan rectifier kemudian inverter (frekuensi konverter) digunakan untuk mengubah kembali tegangan searah (dc) yang dihasilkan rectifier menjadi tegangan bolakbalik (ac) dengan frekuensi dan tegangan yang dapat diatur. Untuk motor ac 3 fasa digunakan inverter jembatan tiga fasa (frekuensi konverter tiga fasa). Namun terdapat kendala dalam menghasilkan sinyal sinusoidal kontrol tiga fasa variabel frekuensi. Penggunaan komputer untuk menghasilkan sinyal tersebut menyebabkan inverter tidak praktis untuk dapat dibawa kemana-mana (tidak portable). Jika menggunakan operational amplifier (op-amp) sebagai penggeser fasa gelombang sinus $0^{\circ}$ menjadi $120^{\circ}$, frekuensi sinusoidal tidak dapat diatur-atur, karena sudut pergeseran fasa yang 
dihasilkan penggeser fasa op-amp dipengaruhi oleh besar frekuensi sinusoidal $0^{\circ}$.

Solusinya adalah dengan menggunakan Flash PEROM (Programmable Eraseable Read Only Memory) mikrokontroller AT89C51 (keluarga MCS51) sebagai penghasil sinyal sinusoidal tiga fasa variabel frekuensi. Alternatif lain dapat digunakan $U V$-EPROM (Ultra Vilolet Eraseable Programmable Read Only Memory). Alasan digunakan Flash PEROM karena harganya yang jauh lebih murah ketimbang $U V$-EPROM, selain itu Flash PEROM mudah dihapus dan diisi ulang serta mudah diaplikasikan untuk keperluan lain. Pada $U V$-EPROM proses penghapusan harus melakukan penyinaran sinar ultraviolet pada jendela $U V$-EPROM.

\section{RANCANGAN}

Secara umum blok diagram rancangan rangkaian kontrol $S P W M$ tiga fasa yang akan dibuat adalah seperti pada Gambar 1.

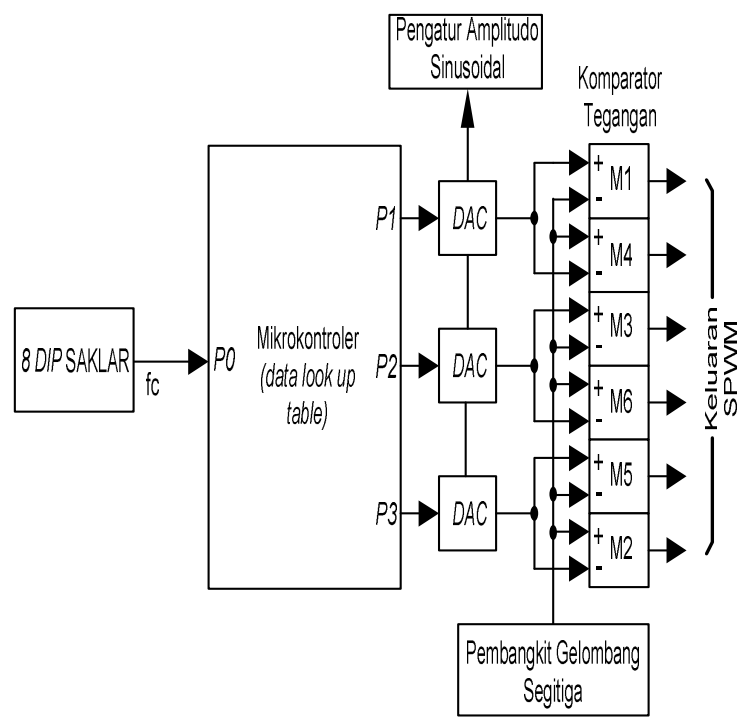

Gambar 1. Blok diagram rancangan

Pembangkit sinyal kontrol sinusoidal inverter tiga fasa yang akan dirancang merupakan ekivalen digital dari sinyal sinusoidal analog yang disimpan pada PEROM mikrokontroller. Sinyal sinusoidal analog disampling atau dipartisi sehingga didapat ekivalen digital untuk masing-masing daerah sampling. Kumpulan dari ekivalen digital sinyal sinusoidal yang didapat sebanyak 256 data (8 bit/1 byte) disimpan dalam tabel data (look up table) pada PEROM mikrokontroller AT89C51. Tabel data kemudian dipanggil dan dikeluarkan satu persatu ke port parallel mikrokontroller $P 1$, $P 2$, dan $P 3$. Antara $P 1, P 2$, dan $P 3$ data yang dikeluarkan digeser $120^{\circ}$ untuk mendapatkan besaran digital sinusoidal yang tergeser $120^{\circ}$ (tigafasa). Kecepatan pemanggilan dan pengeluaran data ditentukan oleh input frekuensi (fc) yang diberikan oleh saklar $8 D I P$ (Dual In Line Package) ke port parallel PO mikrokontroller (look up table), semakin cepat pemanggilan dan pengeluaran data, semakin besar frekuensi sinusoidal yang dihasilkan dan sebaliknya.

Besaran digital sinusoidal yang keluar dari mikrokontoller kemudian diubah menjadi besaran analog oleh Digital-Analog Converter $(D A C)$. Besar amplitudo sinusoidal yang keluar dari $D A C$ dapat diatur dengan memvariasikan nilai tegangan referensi $\left(\mathrm{V}_{\text {ref }}\right)$. Keluaran gelombang sinus dari $D A C$ kemudian dibandingkan dengan gelombang segitiga oleh IC komparator tegangan untuk mendapatkan modulasi lebar pulsa sinusoidal (Sinusoidal Pulse Witdh Modulation / SPWM). SPWM ini merupakan sinyal gate bagi MOSFET inverter jembatan tiga fasa.

\section{A. Rancangan Rangkaian Penggerak SPWM Inverter Tiga Fasa}

1. Pembangkit Gelombang Segitiga

Pembangkitan gelombang segitiga digunakan rangkaian ICL8038CCPD seperti yang ditunjukkan oleh Gambar 2.

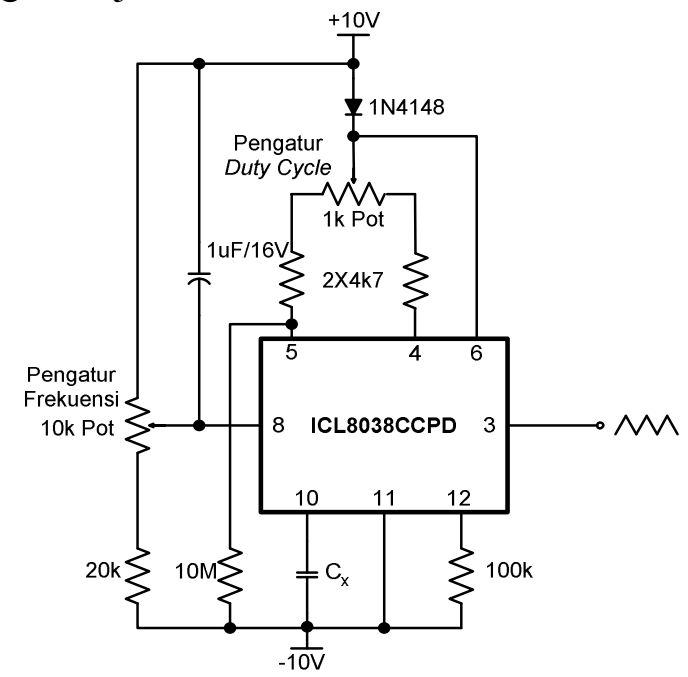

Gambar 2. Rangkaian pembangkit gelombang segitiga 
Untuk memperbesar amplitudo tegangan yang dihasilkan oleh pembangkit gelombang segitiga digunakan penguat amplitudo segitiga seperti yang tampak pada Gambar 3 .

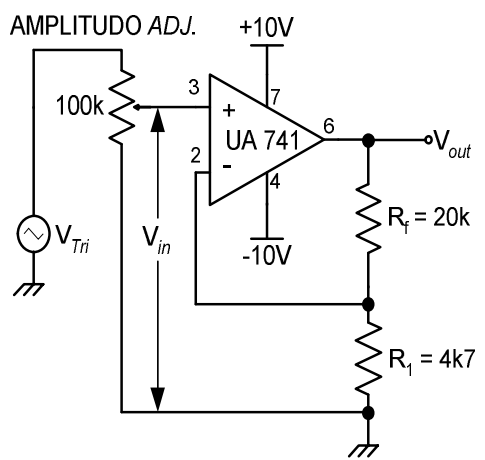

Gambar 3. Penguat amplitudo segitiga

2. Komparator Tegangan

Untuk memodulasi sinyal referensi sinusoidal dengan sinyal carrier segitiga digunakan IC LM311 seperti yang ditunjukkan Gambar 4.

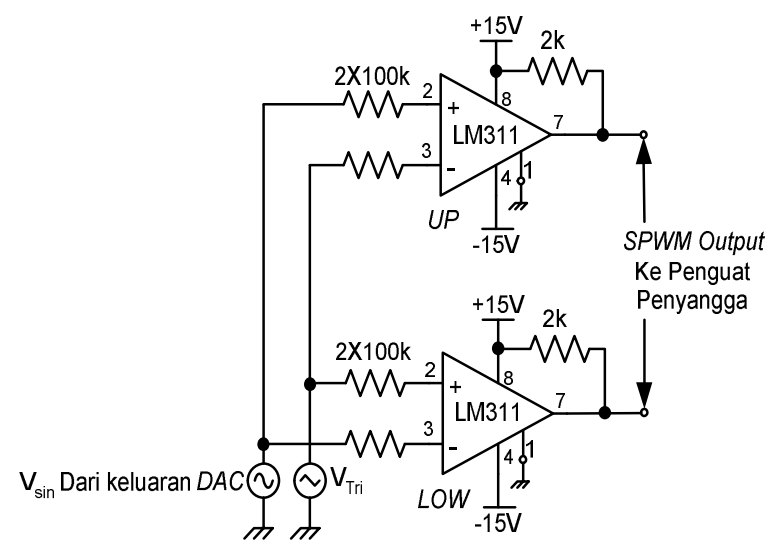

Gambar 4. Rangkaian komparator tegangan

\section{Sistem Mikrokontroler}

Sistem mikrokontroler disini merupakan tempat pembentukan sinyal sinusoidal ekivalen digital yang akan melakukan beberapa urutan tugas, yang diseting baik secara hardware maupun secara software. Urutan tugas yang akan dikerjakan oleh sistem mikrokontroler adalah pembacaan saklar penentu frekuensi sinusoidal, pengambilan tabel datasinusoidal yang ada dalam memori, pencacahan (counter), pemanggilan waktu tunda, perulangan pemangilan data tabel lihat, dan yang terakhir adalah pengeluaran tabel datasecara berurutan ke port.
4. Proses Pembentukan Gelombang Sinusoidal

Seperti yang tampak pada Tabel 1 dan Gambar 5, data yang berhubungan dengan alamatnya ditulis dalam ROM. Data tersebut merupakan ekivalen digital dari sinyal sinusoidal. Berikutnya, ketika bilangan biner alamat diumpankan ke jalur alamat (adrress bus) terhubung dengan $R O M$, data yang bersesuai dengan alamat dikeluarkan hampir pada jalur data (data bus). Kemudian data tersebut terkirim ke jalur data jika sinyal baca (read) diumpankan pada $R O M$.

Tabel 1. Isi dari ROM

\begin{tabular}{|c|c|}
\hline Address & Isi / Data \\
\hline 0 & data 0 \\
\hline 1 & data 1 \\
\hline 2 & data 2 \\
\hline 3 & data 3 \\
\hline$\ldots$ & $\ldots$ \\
\hline 254 & data 254 \\
\hline 255 & data 255 \\
\hline
\end{tabular}

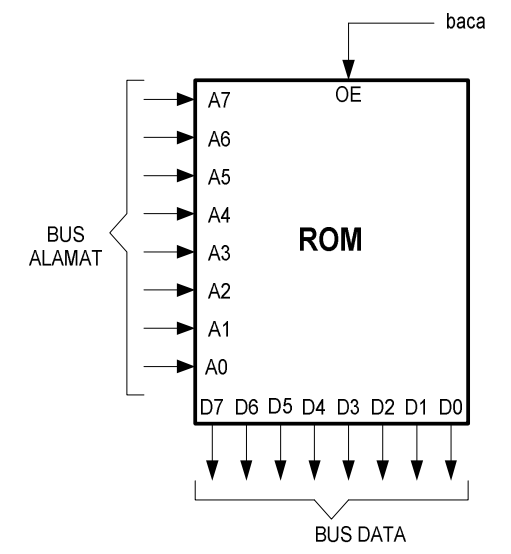

Gambar 5. Hubungan kabel untuk ROM

5. Tabel Data Gelombang Sinus (look up table)

Sin $\theta$ dapat dihitung dengan perangkat lunak. Metoda ini cukup rumit, metoda sederhana dan akurat adalah dengan membuat tabel data (look up table). Nilai untuk setiap $\theta$ disimpan dalam memori secara berurutan. Untuk keluarannya ke $D A C$, memori untuk $\theta$ diakses.

Perhitungan nilai digital ${ }^{[9]}$ : 


$$
=\frac{360}{256} \times \text { memory address }=\frac{360}{256} \times 0001=1.40625
$$

$\sin \theta=0.02454$

Bits $=\sin \theta \times 128=3.14127$

Karena itu digit sebelum koma desimal adalah $3,14127=3($ desimal $)=00000011$ (biner, bit). Nilai biner yang akan disimpan ke $R O M$ adalah $=10000000$ (nilai dasar dari $D A C$ $=80 \mathrm{H})+00000011$ (nilai hasil pembulatan) $=$ $10000011(83 \mathrm{H})$. Persen kesalahan dapat dihitung untuk mendapatkan representasi gelombang sinus yang akurat dengan persamaan [9]:

$$
\% \text { Error }=\frac{(\sin \theta \times 128) \text { pembula } \tan }{(\sin \theta \times 128)} \times 100 \%
$$

\section{B. Rancangan Perangkat Keras}

Gambar 6 memperlihatkan mikro-kontroller AT89CX051 yang dihubungkan ke DAC0800 buatan National Semi-conductor.

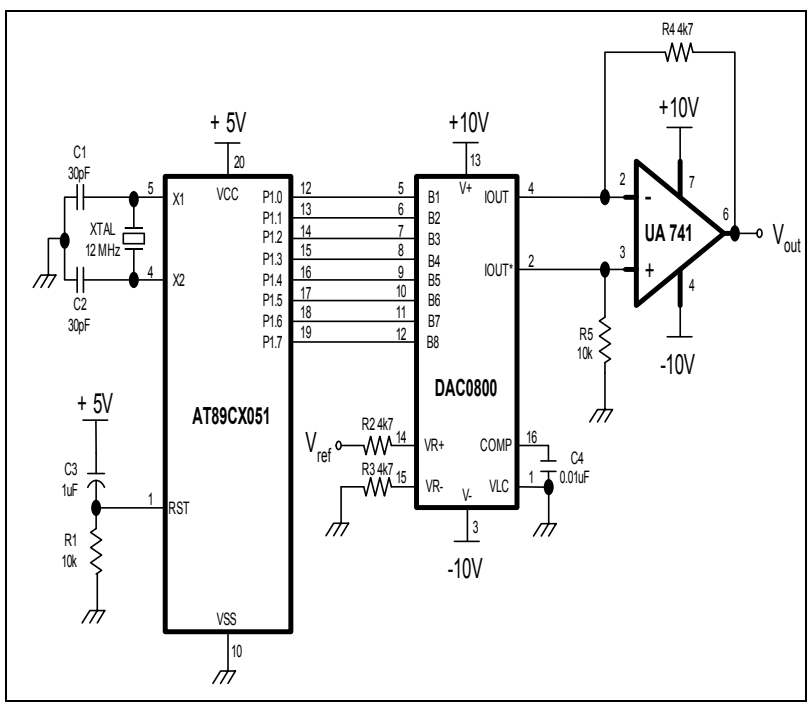

Gambar 6. Hubungan AT89CX51 dengan DAC0800

Nilai amplitudo maksimum sinusoidal FFH dan nilai minimum amplitudo $00 \mathrm{H}$, seperti yang diperlihatkan Gambar 7 (a) dan (b).

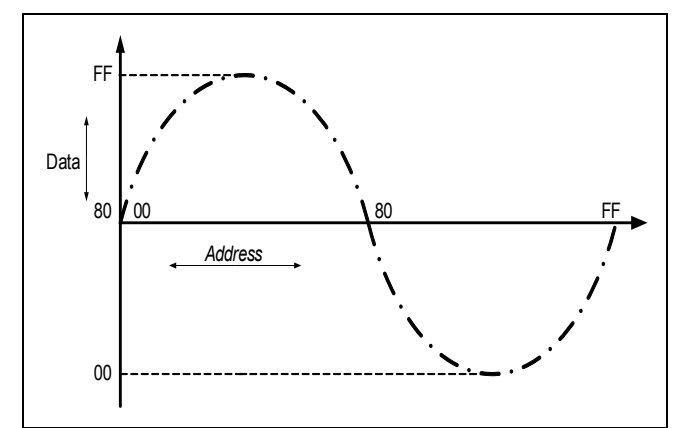

(a)

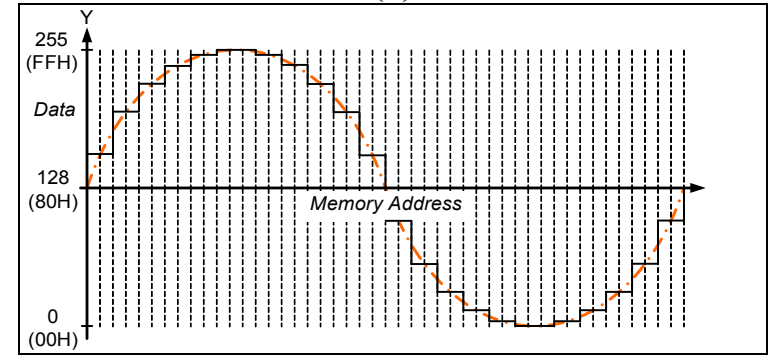

(b)

Gambar 7. (a) Isian data dan alamat ROM (b) Sinusoidal keluaran DAC

Pada Gambar 7(b), diperlihatkan garis putus-putus warna merah merupakan sinusoidal asli/fundamental sedangkan garis tebal berbentuk anak tangga di sekitar garis putusputus merupakan hasil keluaran analog dari $D A C$.

Skema rancangan sistem mikrokontroler untuk pembangkitan sinyal sinusoidal tiga fasa :

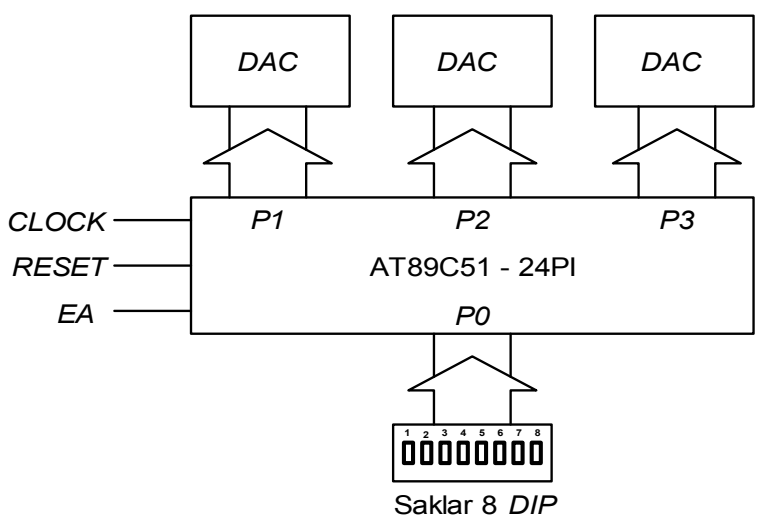

Gambar 8. Skema rancangan sistem mikrokontroler

\section{PERANGKAT LUNAK}

Gambar 9. menunjukkan diagram alir pemograman dari proses pengeluaran data ekivalen digital sinyal sinusoidal tiga fasa dan pengambilan data (input) frekuensi. 


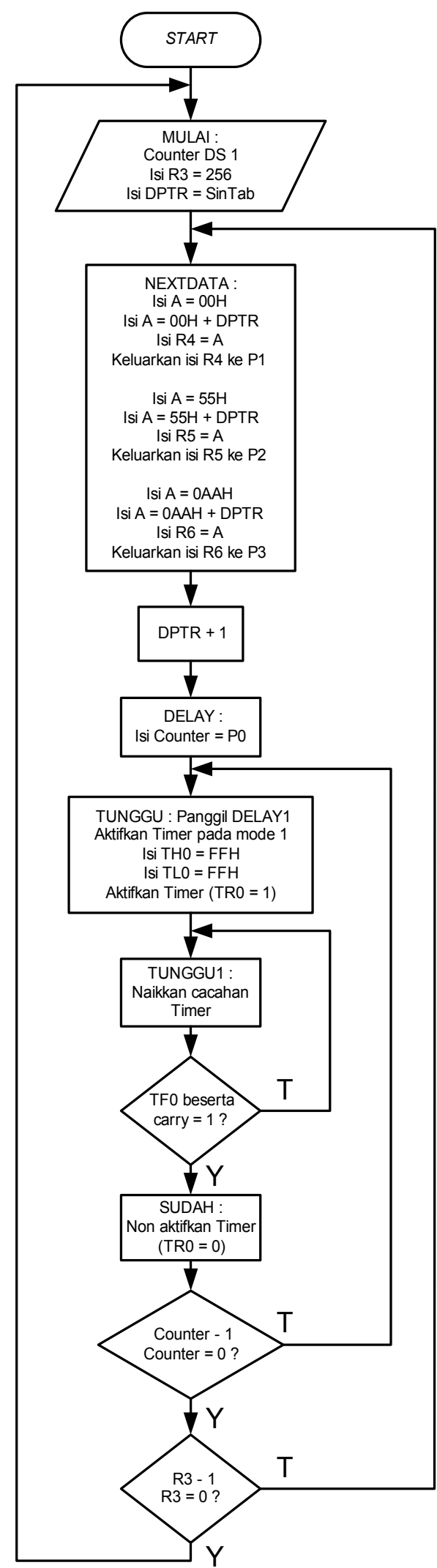

Gambar 9. Diagram alir pemrograman

Dari diagram alir tersebut dibuat program bahasa assembler standar 8051 / AT89C51 dengan perangkat lunak "pinnacle 52 Professional Development System Ver 1.330 " untuk pengubahan file program bahasa assembler yang berektensi .asm menjadi .hex.

\section{HASIL DAN PEMBAHASAN}

Hasil rancangan rangkaian kontrol $S P W M$ tiga fasa telah diujicobakan di Laboratorium Konversi Energi Elektrik Unand. Pengujian rangkaian kontrol $S P W M$ tiga fasa pada frekuensi konverter tiga fasa dilakukan saat kondisi tanpa beban dan saat kondisi berbeban. Beban yang digunakan disini adalah berupa beban statis (beban resistif murni) dan beban dinamis motor induksi tiga fasa $692 \mathrm{~V} \mathrm{Y}, 270$ W, 1350 rpm, 0,58 A, 4 kutub, Leybold Didactic Gmbh.

\section{A. Keluaran Rangkaian Penggerak $S P W M$}

1. Pembangkit Gelombang Sinusoidal

Sinyal kontrol yang dihasilkan oleh mikrokontroler merupakan gelombang sinusoidal tiga fasa berbeda fasa $120^{\circ}$ yang masih berupa ekivalen digital. Kemudian oleh rangkaian $D A C$, sinyal ekivalen digital sinusoidal tiga fasa tersebut diubah menjadi besaran analog seperti yang terlihat pada Gambar 10.

Dari Gambar 10 dan 11 tampak bahwa besar $\mathrm{A}_{\mathrm{C}}$ yang dihasilkan adalah sekitar $10 \mathrm{~V}$ dengan $T H D$ tegangan $0,2 \%$ untuk frekuensi $36,1 \mathrm{~Hz}$ dan $57,4 \mathrm{~Hz}$.

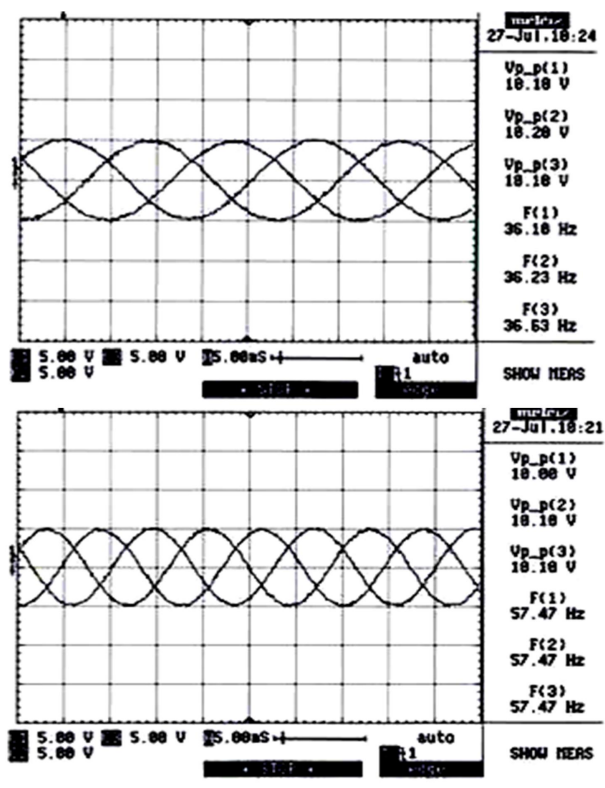

Gambar 10. Keluaran sinusoidal rangkaian $\mathrm{DACf}_{\mathrm{C}}=36,1 \mathrm{~Hz}$ dan $57,4 \mathrm{~Hz}$ 


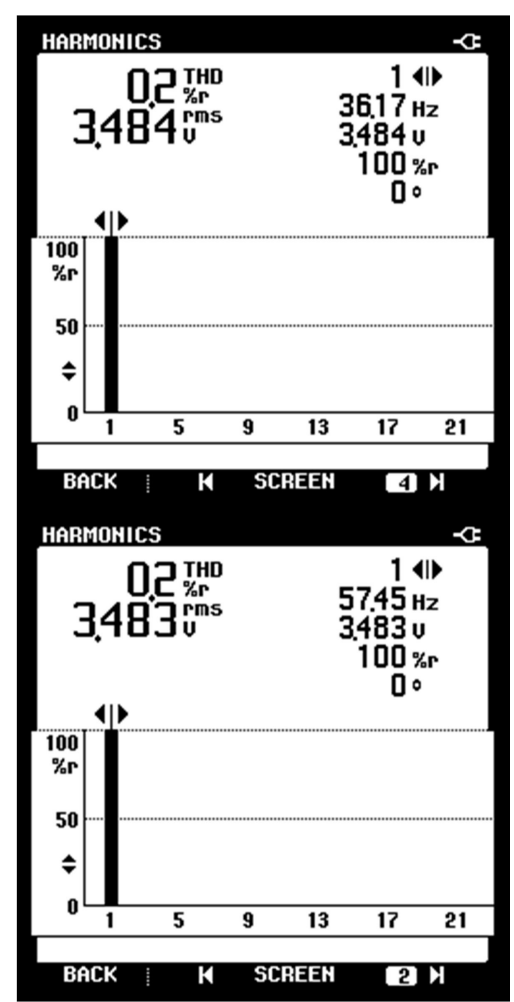

Gambar 11. THD dan spektrum harmonisa keluaran sinusoidal rangkaian $\mathrm{DACf}_{\mathrm{C}}=36,1 \mathrm{~Hz}$ dan $57,4 \mathrm{~Hz}$

2. Pembangkit Gelombang Segitiga

Gambar 12 menunjukkan bentuk sinyal segitiga. Besar $\mathrm{f}_{\mathrm{T}}$ yang dipilih $500 \mathrm{~Hz}$ dikarenakan keterbatasan waktu pensaklaran optocoupler.

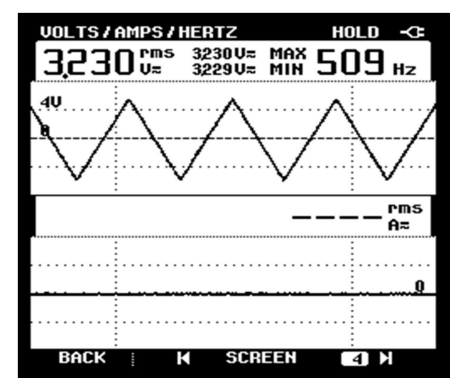

Gambar 12. Sinyal segitiga $\mathrm{f}_{\mathrm{T}}=500 \mathrm{~Hz}$

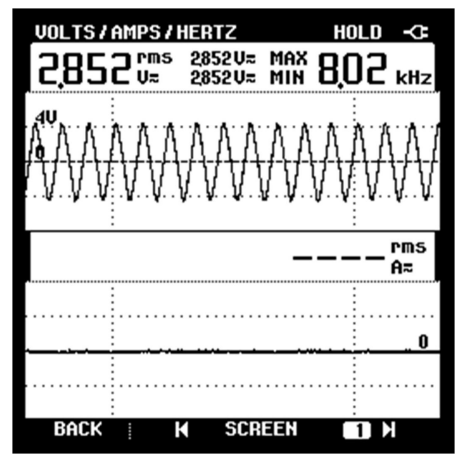

Gambar 13. Sinyal segitiga $\mathrm{f}_{\mathrm{T}}=8 \mathrm{kHz}$

\section{Komparator}

Keluaran dari komparator LM311 adalah sinyal pembandingan antara sinyal sinusoidal sebagai sinyal kontrol dengan sinyal segitiga sebagai sinyal pembawa.

Sinyal masukan dan keluaran dari komparator seperti yang ditunjukkan gambar 13 dibawah. Sinyal untuk MOSFET 4, 6, dan 2 adalah kebalikan dari sinyal MOSFET 1, 3, dan 5, seperti yang ditunjukkan Gambar 14.

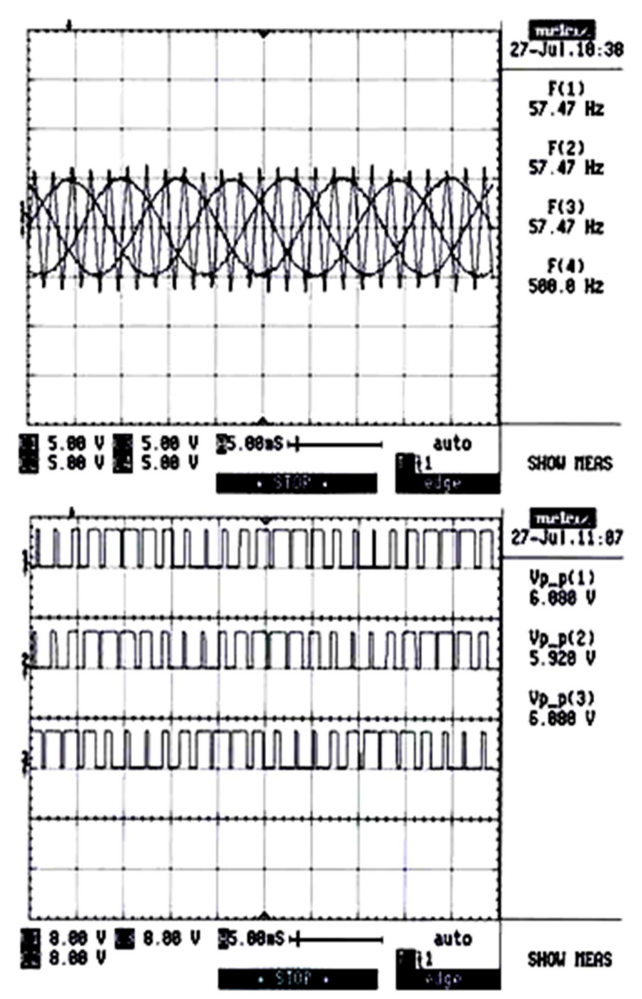

Gambar 13. Sinyal masukan dan keluaran Komparator untuk gate MOSFET 1,3 , dan $5 \mathrm{f}_{\mathrm{T}}=500 \mathrm{~Hz}$

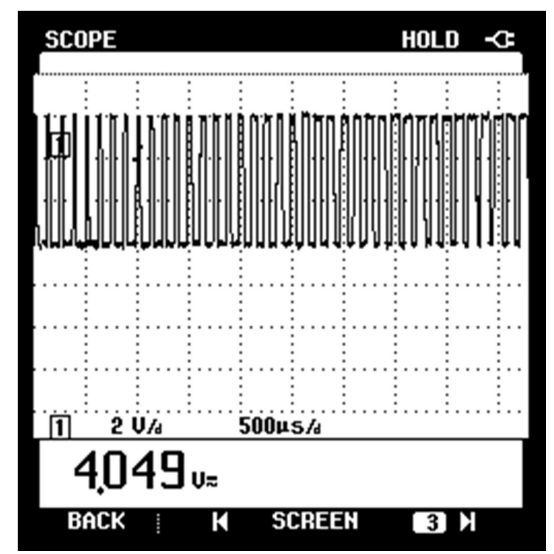

Gambar 14. Sinyal masukan dan keluaran Komparator untuk gate MOSFET $1 \mathrm{f}_{\mathrm{T}}=8 \mathrm{kHz}$ 


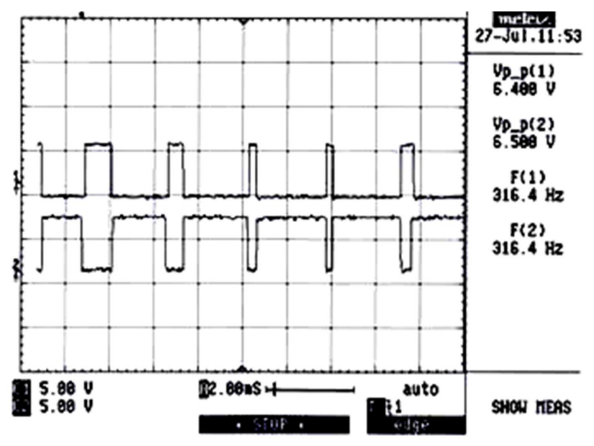

Gambar 15. Gelombang keluaran komparator LM311 yang saling berbalikan

\section{KESIMPULAN DAN SARAN}

Dari hasil pengujian alat dan analisa dapat diambil beberapa kesimpulan :

1. Pada penelitian ini, telah berhasil dirancang rangkaian penggerak $S P W M$ tiga fasa dengan menggunakan mikrokontroler AT89C51 untuk pemakaian beban statis dan dinamis.

2. Pembebanan frekuensi konverter tiga fasa pada motor induksi menghasilkan bentuk gelombang arus keluaran frekuensi konverter yang mendekati sinusoidal. Hal ini disebabkan karena motor induksi yang merupakan beban induktif dapat bekerja sebagai filter arus dari inverter.

3. Pengujian frekuensi konverter pada beban dinamis dengan memvariasikan frekuensi sinusoidal kontrol didapatkan besar kecepatan putaran motor induksi yang mendekati sama dengan kecepatan putaran sinkronnya secara perhitungan. Pengaturan kecepatan putaran motor induksi tiga fasa dilakukan dengan mengatur nilai frekuensi keluaran sinusoidal pada mikrokontroler.

Saran untuk rancangan rangkaian penggerak $S P W M$ tiga fasa : rancangan rangkaian penggerak $S P W M$ tiga fasa ini memiliki keterbatasan dalam hal penentuan frekuensi sehingga hanya dapat bekerja pada frekuensi tertentu saja dengan kenaikan frekuensi yang tidak linier sehingga dibutuhkan modifikasi program pada mikrokontroler.

\section{REFERENSI}

[1]. Rasyid, M. H. (1993). Power Electronics, Circuits, Devices, and Application, Prentice-Hall International Inc.

[2]. Mohan Ned, M. (1996). Power Electronics : Converters, Applications, and Design, John Wiley \& Son, New York.

[3]. Coughlin, R. F. (1985). Penguat Operasional dan Rangkaian Terpadu Linear, Erlangga, Jakarta.

[4]. Agfianto, Eka P. (2004). Belajar Mikrokontroler AT89C51/52/55, Gava Media, Yogyakarta.

[5]. Paulus, Andi N. (2003). Panduan Praktis Teknik Antarmuka dan Pemograman Mikrokontroler AT89C51, Elex Media Komputindo, Jakarta.

[6]. Intel Corporation (2004). Technical Note MCS51-FX Microcontrollers : Generating Sine Wave With 8051Fx's PWM Generator, http://www.intel.com/design/mcs51/techno te/Intel (R) MCS (R) 51-251 Microcontrollers.htm.

[7]. Ahmed, A. (1999). Power Electronics for Technology, Prentice-Hall, New Jersey.

[8]. Sutanto, B. (2001). Menghubungkan Mcs ke Dunia Analog, http://www.alds.stts.edu /Digital/DA-ADC.htm.

[9]. Setya, A. David (2001). Function Signal Generator, http://www.geocities.com/dsaproject/electr onics/f gen.htm\#DATA LOOK UP TAB LE. 